\title{
マイクロ・ナノテクノロジーと検査技術
}

庄子 習一*

ナノテクノロジーは 21 世紀の技術として注目されて いるが，バイオへの応用という観点からもその捉えかた は研究者によって様々であり，その研究動向を系統的に 解説するのは不可能である。そこで, 本稿では半導体微 細加工技術を利用した，化学/生化学分析あるいは合成 システムのダウンサイジング化に限ってその研究動向を 述べる。1980 年代の半ば頃より, 半導体微細加工技術 や精密加工技術を応用し, 微小機械素子や回路素子から なる機能的な小型システムを実現する Micro Electro Mechanical Systems（MEMS）の研究が盛んに行われ ている。近年，米国を中心にこの技術により作られるマ イクロチップをゲノム解析に代表されるようなバイオテ クノロジー分野へ応用する動きが盛んで世界的に注目さ れている。それに対して, 日本や欧州では化学産業への 応用より高度な MEMS 技術による化学/生化学システ ムのダウンサイジング化の動きが始まっている。

MEMS 技術の化学分析分析システムへ応用した例は 以下の 2 つに大別される。1つはマイクロバルブやマイ クロポンプなどのマイクロ流体素子とマイクロセンサを 集積化した MEMS 型マイクロ化学分析システムであ る。もう 1 つは MEMS 技術を利用して作るマイクロ電 気泳動チップである。後者はゲノム解析のプロジェクト と結びついて, 米国を中心に研究が盛んになり今日に 至っている。これは分析化学分野の研究者のニーズから 出発したのアプローチで, 構造や原理が単純なところか ら最初に実用化するに至っている。現在, アジレントテ クノロジー, 日立製作所, 島津製作所などにより分析シ ステムとして市販されている。また, Affimetrix 社に よる DNA チップの集積回路製造に用いられるフォトリ ソグラフィ技術の生化学分析への応用が見られるように MEMS 技術のバイオテクノロジーへの応用が加速され ている。

現在，米国を中心に最も盛んに研究が行われているの はDNA 分析を対象とした $\mu$ TAS である。この背景に はDNA の増幅方法である Polymerase Chain Reaction：PCR 法の確立がある。この方法は 2 本鎖 DNA の単鎖への分離, DNA 合成酵素による 2 本鎖の DNA の合成を繰り返し，DNA 增幅を行うものである。この

\footnotetext{
* 早稲田大学
}

反応過程はそれぞれ違う温度で起こり，熱サイクルを高 速に切り替えれば DNA 増幅が短時間で行える。このた め, マイクロマシーニングを用いて熱容量の小さいマイ クロ反応容器を作ると効率の良い DNA 増幅が可能とな る。DNA 生成の検出に蛍光酵素を用いて PCR により 増幅された特定の DNA を光学的に検出する装置が製作 されている。多数のマイクロ反応セルが形成されたシリ コンチップを CCD カメラで一括して観察することによ り, 効率の良いDNA 分析が実現されている。

DNA チップとは組み合わせの異なる比較的短い塩基 列の単鎖の DNA プローブを基板上にマトリックス状に 形成したものである。DNA 鎖の形成にはフォトリソグ ラフィ技術を応用している。チップに蛍光酵素をラベル したサンプル DNA を導入すると, DNA 配列の一致し たものだけが DNA プローブと強く結合し基板上に固定 される。その後, 未結合のサンプル DNA を洗浄したあ と励起光を照射すると固定された DNA のある部分だけ が蛍光を発する。この蛍光パターンをコンピュータ解析 することにより，極めて短時間に DNA の配列を決定す ることが可能である。その有効性はまだ評価の段階にあ るが，新しいDNA 分析方法として注目されている。こ の DNA チップと PCR を行う流体システムを集積化す る研究も行われている。

化学/生化学分析の現場の要求に答えうるものとして, マイクロ流体システムという概念がある。マイクロポン プ, マイクロバルブ, サンプルインジェクタ, 混合・反 応器 (リアクタ), 分離器, 検出器などの要素を並べた 相互を基板の中の流路やチューブにて繫ぎシステムを構 成するものである。それぞれの要素を用途により最適設 計したうえで基板上に並べる方式は, ちょうど電子回路 をプリント基板上に作るのと同じ発想である。この発想 は MEMS 研究者のシーズ側の発想であり, 本当の意味 での化学プロセス，化学分析を実現するためには設計思 想の中には流体力学的な発想と化学反応を融合させた理 論的裏付けが必要である。ところで, システム中の MEMS 的要素としてのマイクロ流体素子の性能はシス テムの機能を決めるもので最も重要である。これまで, 様々なマイクロシステムの提案が行われてきているが, 実用に供するものはまだ少ないのが現状である。しかし， 今後サンプルの前処理を含めた自動化マイクロシステム 


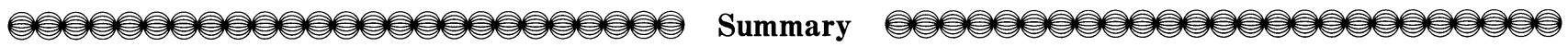

\section{Nanotechnology and Micro System Technology for Laboratory Test}

\section{Shuichi SHojI}

Micromachine technologies have been applied to miniaturize chemical and bio-chemical total analysis systems. Micro/miniaturized total analysis systems ( $\mu$ TAS), developed so far, classified into two groups. One is a MEMS (Micro Electro Mechanical System) type system using pressurized flow by mechanical flow control devices, for example, microvalves and micropumps. The other uses electrically driven liquid handling without mechanical elements. Typically electroosmotic flow has been used so far. Planer capillary electrophoresis (chip CE) type systems are the common application of this method. Micromachine technologies of etching, bonding, plastic molding and sophisticated combined processes used for fabricating these $\mu$ TAS are reviewed. Micro flow control devices of micropumps and microvalves applied for $\mu \mathrm{TAS}$ are also introduced. 